\title{
Sex Manipulation Technologies Progress in Livestock: A Review
}

\author{
Yanshe Xie ${ }^{1,2 t}$, Zhiqian $\mathrm{Xu}^{1,2 t}$, Zhenfang $\mathrm{Wu}^{1,2 *}$ and Linjun Hong ${ }^{1,2 *}$ \\ ${ }^{1}$ Guangdong Provincial Key Laboratory of Agro-Animal Genomics and Molecular Breeding, National Engineering Research \\ Center for Breeding Swine Industry, College of Animal Science, South China Agricultural University, Guangzhou, China, \\ 2 Lingnan Guangdong Laboratory of Modern Agriculture, Guangzhou, China
}

\section{OPEN ACCESS}

Edited by:

Arumugam Kumaresan,

National Dairy Research Institute (ICAR), India

Reviewed by: Inmaculada Parrilla, University of Murcia, Spain Martin G. Maquivar, Washington State University, United States

*Correspondence: Zhenfang Wu wzf@scau.edu.cn Linjun Hong

Linjun.hong@scau.edu.cn

tThese authors have contributed equally to this work

Specialty section:

This article was submitted to

Animal Reproduction -

Theriogenology,

a section of the journal

Frontiers in Veterinary Science

Received: 08 May 2020

Accepted: 29 June 2020

Published: 14 August 2020

Citation:

Xie Y, Xu Z, Wu Z and Hong L (2020)

Sex Manipulation Technologies

Progress in Livestock: A Review.

Front. Vet. Sci. 7:481

doi: 10.3389/fvets.2020.00481
Sex manipulation technologies allow predetermination of the sex of animal offspring by altering the normal reproductive process. In livestock production, the difference in type and gender can translate into significant economic benefits, including alleviation of severe food shortages. In livestock, however, the commercial application of sex manipulation technologies is currently available for cattle only. In this review, we described the brief history of sex manipulation, and the research progresses of common methods used in sex manipulation thus far. Information presented in this review can inform future studies on expanding the scope and use of sex manipulation technologies in livestock.

Keywords: sex manipulation, sperm separation, female reproductive tract, embryo sexing, livestock

\section{INTRODUCTION}

By 2050, the world's population is expected to increase by 9.6 billion, and the demand for livestock products, by 70 percent (1). Most of the population growth is however expected to occur in developing countries, where currently most croplands in production face challenges in coping with urbanization, biofuel production, and climate change (2). Therefore, to meet the forecasted global food demand, utilizing modern biotechnologies to promote sustainable production of livestock will be essential. Sex manipulation technologies are biotechnologies that can selectively predetermine the sex of animal offspring by intervening the normal reproductive process, and besides playing an important role in solving food shortage problem, it can address issues related to animal welfare such as castration. In this review, our objective was to provide suggestions for future research to improve sex manipulation technologies in livestock.

\section{THE ORIGIN AND DEVELOPMENT OF SEX MANIPULATION}

In ancient times, boys were also preferred to girls since besides being more likely to appease the wrath of the gods, they were regarded to be a strong support for the elderly (3). The preference for producing male offspring therefore promoted sex manipulation research (4).

Theories of what determined the sex of an individual transited from myths to science in the 17th century. In 1651, William Harvey compared the reproductive organs of several animals and stated that "all animals whatsoever, even viviparous creatures, man himself, are all engendered from an egg" (5). Later on, in the 1670's, AntonieVanLeeuwenhoek discovered a microscope which he used to observe sperm cells in human and dog seminal fluid. This discovery became a turning point in the research of sex manipulation (6).

In 1905 while studying the mealworm beetle Tenebrio molitor, Nettie Maria Stevens found that unlike in females, one chromosome was smaller than others in males. She concluded that the shorter chromosome was the "Y" chromosome, and was responsible for sex determination alongside the larger chromosome, which she named chromosome "X" (7). 
By the end of the 1950's, the Y chromosome's role in determining the male sex was undisputed. Thus, over the next few decades, efforts were geared toward identifying a single testis-determining factor (TDF) in humans. In 1990, researchers found a $35-\mathrm{kb}$ region from $\mathrm{Y}$ chromosome in four masculinized XX patients. Southern blotting revealed that the Y-fragment was the likely carrier of the TDF gene (8). Sequencing showed that an open reading frame (ORF) encoded a single-exon gene named the "sex-determining" region of the "Y chromosome" (SRY in humans) (9). Further, researchers found that $S R Y$ up-regulated the expression of SOX9 in somatic (pre-Sertoli) cells of the genital ridge (10). Besides the relationship with autosomal sex reversal and Campomelic Dysplasia (CD) in human (11), SOX9 can activate the expression of genes required for Sertoli cell differentiation [e.g., FGF9 (12)], causing the re-expression of genes associated with ovarian development [e.g., WNT4 (13)]. Importantly, SOX 9 also promotes its own expression, thereby bypassing the testicular differentiation that requires sustained $S R Y$ expression (14). Therefore, the discovery of SRY on the $\mathrm{Y}$ chromosome was a major breakthrough in the mammalian sex determination theory and promoted the development of sex manipulation technologies by providing a theoretical basis. Thereafter, the research on sex manipulation technologies gained traction with various studies seeking to enhance the respective existing technologies. Herein, we discussed the advances in sex manipulation technologies in animals with a focus of providing an informative insight for future development.

\section{SEX SELECTION STRATEGIES DURING SPERMATOGENESIS}

The independent orientation of homologous chromosome pairs along the metaphase plate during metaphase I of meiosis and the subsequent separation of homologs and sister chromatids during anaphase I of meiosis allow an independent distribution of X or Y chromosomes to each secondary spermatocyte (15). During meiosis, some genes encode proteins with essential roles in structures or functions specific to spermatogenic cells, are expressed in developmentally regulated patterns, and are transcribed only in, or produce mRNAs unique to, spermatogenic cells (16). Therefore, the expression of these genes can regulate the ultimate meiotic stage-specific protein expression and change the ratio of $\mathrm{X}$ - and Y-bearing sperm during spermatogenesis.

In recent years, with the development of molecular biology and cell biology, there were more and more sex-determining genes being identified, including Sry (17, 18), Amh (19), Sox family (10, 20, 21), Dmrt1 (22), Fgf9 (23), Gata4 (24), etc., which are associated with male sex determination, and Wnt4 (25-27), Dax1 (28), Rspo1 (29, 30), Foxl2 (27, 31-33) associated with female sex determination. Presently, gene edit and RNA interference targeting these sex-determining genes are the main methods often used to bias the ratio of X-and Y-bearing sperm during spermatogenesis.

The emergence of gene editors such as zinc finger nucleases (ZFN), transcription-activator-like endonucleases (TALENs), and the clustered regularly interspaced short palindromic
repeats/Cas endonucleases (CRISPR/Cas) system has offered great potential in the selection of sex at the gene level (34).

Successful ZFN-mediated disruption of a sex-determining gene in rainbow trout (35) and the generation of Sry knockout mouse via oocyte injection using TALEN (36) have since been reported. However, standard molecular biology laboratories cannot afford the demand of ZFN molecules because most ZFN molecules are commercial. Although TALENs are more effective than ZFNs, the design of TALEN is complicated and time-consuming due to the high amounts of plasmids involved. Moreover, the specificity of TALEN to target the expected DNA sequences remains unconfirmed. The CRISPR/Cas system is superior to ZFNs and TALENs due to its ease of use and cost-effectiveness, provided a molecular biology laboratory has access to CRISPR kits. Besides, the CRISPR/Cas system can identify and induce mutation on target loci with high specificity (37). Although these gene editors cannot be used in livestock production presently, the CRISPR/Cas system is the most suitable technique for sex selection among them.

The CRISPR/Cas system is usually introduced into zygotes via microinjection $(38,39)$ or combined with somatic cell nuclear transfer or surgical transfer to generate offspring (40). Recently, researchers have biased the sex ratio of populations of different organisms such as plants, insects, crustacean, and fish, at the gene level (41). The CRISPR/Cas system has been used to control agricultural pest through female-elimination approaches that give rise to more males in an insect population. Such a rise can either result in a population decrease or eliminate the population occasioned by the lack of females (42).

A recent study in mice described a new strategy to bias the sex ratio of the offspring. Three CRISPRguide RNAs targeting three autosomal genes which are essential for early development in mouse were encoded on murine $\mathrm{Y}$ paternal line, while the CRISPR-Cas9 enzyme was encoded into the maternal line. After fertilization, both the Y-encoded guide RNAs from the paternal sperm and the Cas9 protein from the maternal egg targets resulted in self-destructing males (41). The high homology of the Sp1-binding site between humans and rabbits makes the latter a suitable animal model for studying the clinical male-to-female sex reversal syndrome in humans. The first rabbit hermaphroditism model was recently generated using the CRISPR/Cas9 system. Ten potential off-target sites were analyzed by Sanger sequencing and the T7E1 assay to determine whether off-target effects occurred in the SRY mosaic rabbit. To determine whether chimeric mutations in the SRY gene induced hermaphroditism, the internal genitalia of $S R Y$-mutant chimeric rabbits were also analyzed. The generation of the model provided a platform to understand the pathogenesis of hermaphroditism and identify novel therapies for human clinical hermaphroditism with male-to-female sex reversal syndrome (43).

Gene editing technology requires highly skilled personnel, and the lack of a clear role of the sex-determining gene in livestock sex determination hinders its application in this field (34). However, the optimization of the existing gene editors, the development of new gene editors, and continued research on the sex-determining gene will aid in breaking the barrier. However, there has been a long running debate over whether bio-technologies 
should be applied into food production. Although, many of GM (genetically modified) organisms are already deemed safe, the safety of GM food has been questioned by the general public ever since their introduction in the late 90's $(44,45)$, which hindered the development of bio-technologies in food production. Therefore, government may play an important role in driving the bio-technologies in food production forward by setting stricter food quality standards, improving legal regulation on GM food, and choosing a mandatory GM food labeling system to protect the consumer's right to know. Changing the sex ratio of offspring at the gene level cannot only promote the development of livestock production but also provide a therapeutic biological model for human diseases.

RNA interference (RNAi) is a biological process that uses small interfering RNA (siRNA) to induce sequence-specific gene silencing through mRNA degradation (46). Since its first use in mammalian cells in 2001, RNAi technology has successfully been implemented in mammalian gene silencing systems (47). Genes such as Sry, zfy, and $z f x$ that are known to affect sex determination during spermatogenesis could be silenced through RNAi to influence the sex ratio of animal offspring.

Research has demonstrated that injecting RNAi vectors into mouse testis can skew the sex-ratio of offspring (48). In a separate study, knocking out Sry mRNA by direct injection of siRNA into pregnant mice through the tail vein generated mouse embryos with feminized gonads (49).

The mechanisms of these sex-determining genes in spermatogenesis and sex determination are uncertain, and very little is known on whether these genes could be knockeddown using RNAi technology or the CRISPR/Cas9 system. This is because the expression level of mRNA is influenced by several factors including non-specific creation, the activation of innate immune response, and off-target effects. In addition, transfection protocols yield low efficiency for primary cells, while suspension requires optimization for different cell types. Besides, poor bioavailability, rapid hydrolysis, and the inability to cross biological barriers such as the blood-brain barrier are some of the major concerns that hinder RNAi adoption. However, it has been established that exosomes can transfer siRNAs with high target specificity and without any immunologic reactions as a natural vehicle, thereby providing a new method for delivering of siRNAs into the cells (50).

Primarily, RNAi is a simple method that has had a significant effect on the expression of the sex-determining gene. Future studies should therefore explore the mechanisms of sex-determining genes in spermatogenesis and sex determination, improve transfection efficiency, and reduce electropuncture damage. Besides, using exosome as a vehicle for targeted delivery has good prospects for the future.

\section{SPERM-SEPARATING TECHNOLOGIES IN SEX MANIPULATION}

Several methods have been previously used for separating X-and Y-bearing sperm. The initial sperm sexing procedures designed for sex determination involved DNA probes $(51,52)$, albumin gradients $(53,54)$, Percoll gradients $(55,56)$, the Sephadex gel-filtration method (57-59), and "swim-up" procedures (60, 61). However, the efficiency of these methods in distorting the sex ratio of livestock offspring has been unconvincing (62). Additionally, all these methods can damage sperm motility. Therefore, flow cytometry and immunology sexing are the main sperm separating technologies presently used in livestock production at present.

\section{Flow Cytometry in Sex Manipulation}

Johson et al. was the first to use flow cytometry to separate sperm according to the difference of DNA content in the head of X-and Y-bearing sperm (the DNA content of X-bearing sperm is 3-4\% higher than that of Y-bearing sperm) in $1986(63,64)$. Since then, flow cytometry-based sperm sexing has produced millions of presexed offspring in different species including, rabbits, pigs, cattle, sheep, horses, dogs, cats, etc.

Generally, contemporary sperm-sorting procedures yield a skewed offspring sex ratio of between 85 and 95\% accuracy (65). Flow cytometry has since reached commercial application in cattle (66), and the quality of sperm for use in a flow sorter is dependent on the species. Therefore, the sorting index of different species is calculated by multiplying the percentage of the difference in DNA content of the X- or Y-bearing sperm by the area of the flat profile of the sperm head. The sorting index indicates that bull and boar sperm are well-suited for separation in a flow sorter (133 and 115, respectively) (67). However, use of flow cytometry to sort sperm is minimal in pig production. This could be a result of boar sperm being more susceptible to the influence of flow cytometry since the sorting process damages the boar sperm membrane, which leads to the decline in its vitality, fertilization ability, storage ability, and subsequent processing ability $(68,69)$. In addition, the sperm used for artificial insemination per pregnancy in pig production is often significantly higher than in cattle production $(70,71)$.

Initial studies focused on identifying the steps in flow cytometry that caused sperm damage. It was earlier thought that optimization of sperm dilution rate (72-74), as well as changing the type of dyes and laser power (75-77) could reduce sperm damage. However, these methods could not significantly increase sex-sorted sperm motility. This prompted other researches to focus on improving hardware, optics, electronics, and handling protocols before flow cytometry such as reducing the sheath pressure of the sorter from 50 to 40 psi (78), implementation of pulsed lasers (79), or transportation of red deep sperm at high sperm concentration without staining before sorting (80). Although these improvements increased the motility of sperm after separation, subsequent optimization is limited by current mechanical technology. Besides, improving the production speed and sperm quality remains a significant challenge, thereby shifting attention to related technology.

In a study that aimed to describe the effects of flow cytometry on the structure of the glycocalyx of bovine sperm by using lectin histochemistry, both flow cytometry and capacitation had similar effects on bovine sperm, which may account for the low conception rates observed after flow cytometry (81). Another study that combined AA-2G supplementation 
and deep insemination to improve the fertility of sex-sorted sperm from Cashmere goats revealed a substantial protective effect on the quality and functions of sperm (82). Although some researchers prefer artificial insemination technology, laparoscopic insemination (LI) at the uterine horns can achieve a high fertilization rate with a low sex-sorted sperm dose (five times less than intrauterine insemination) (83). However, improvements such as the outputs of the flow sorters, aspects related to the synchronization protocols, the time of ovulation, and single LI at the uterine horns deserve to be optimized in future studies (84).

In conclusion, flow cytometry is the most used and mature technology for sperm sexing in livestock production, with a separation accuracy of above $90 \%$. However, due to the high sperm requirement and susceptibility of other species, this strategy has only reached commercial application in cattle production. Future studies should therefore focus on reducing sperm damage caused by flow cytometry, develop related technologies, and optimize artificial insemination technology.

\section{Immunology Sexing in Sex Manipulation}

Immunology sexing is achieved through the identification and separation of sex-related proteins. This is mainly done by detecting the $\mathrm{H}-\mathrm{Y}$ antigen on the plasma membrane of Y-bearing sperm by using the H-Y antibody. Thus, far, sperm from many species has been successfully separated including mice (85), rabbits (86), and sheep (87). In addition, because of the simplicity, rapidity, accuracy, and reasonable price of this method, it can be used to verify the purity of sorted X-and Y-bearing sperm (88).

A recent study successfully separated sperm from mice by combining the immunology sexing and swim-up methods, thereby providing a strategy for immunology sexing. In 2019, three Japanese scientists found that Toll-like receptor $7 / 8$, which is encoded by $\mathrm{X}$ chromosome, could influence sperm motility. The motility of $\mathrm{X}$ sperm reduces when incubated with R848 (a synthetic agonist which can bind both TRL8 and TLR7) as a result of Toll-like receptor 7/8 binding R848. However, the motility of the Y sperm is not affected. Thus, the sperm is selectively separated by using the swim-up method, in which Y sperm with high motility swims to the upper layer of the medium, while the $\mathrm{X}$ sperm sinks to the lower layer of the medium. Besides, R848 had no effect on the acrosome of both X sperm and $Y$ sperm, indicating that sperm fertility is not affected even after incubating with R848. In addition, the motility of X sperm returns to normal once $\mathrm{R} 848$ has been washed off. The sperm separated by this method was later used for in vitro fertilization and embryo transfer. In the results, upstream sperm produced 77 blastocyst embryos, among which 68 were XY embryos and 9 were XX embryos, while downstream sperm produced 83 blastocyst embryos, among which 58 were XY embryos and 25 were XX embryos (89).

However, most immunology sexing strategies affect the motility of sperm and reduce the conception rate due to the long processing time. Although this strategy is presently at the laboratory stage, advances in molecular biology may provide more breakthroughs. Therefore, more efforts should be concerted on the discovery of new sex-related proteins and the blending of other strategies to reduce sperm damage.

\section{SEX MANIPULATION WITHIN THE FEMALE REPRODUCTIVE TRACT}

Millions or billions of sperm are deposited into the reproductive tract after mating, but only a few sperm reach the ampulla or the site of fertilization and only one fertilizes an oocyte. The journey that sperm take to reach an oocyte is long and perilous. The female environment contributes toward this successful transit by providing a vehicle for sperm transport, aiding the removal of dead sperm and other pathogens and applying strict selection pressures to ensure only those cells with the highest quality reach the site of fertilization. Besides, in many locations of the female reproductive tract, sperm interact with the epithelium and the luminal fluid, which can affect sperm motility and function $(90,91)$. Although we know little about this complex interaction between sperm and female environment, many researches sought to reveal the impact of the mammalian female on the sex of her posterity.

By introducing $\mathrm{X}$ - or Y-bearing sperm into two separate oviducts of single female pigs using bilateral laparoscopic insemination, researchers demonstrated that the oviduct can screen sperm by modifying the oviduct environment (92). Besides, research has shown that both time of ovulation and maturational state of oocyte can influence the sex ratio of animal offspring $(93,94)$. This led to the investigation of the effect of follicular fluid composition on the sex of an embryo, which was confirmed in subsequent studies $(95,96)$. In addition, various studies have reported the impact of $\mathrm{pH}$ on sperm motility, viability, and capacitation (97). However, $\mathrm{pH}$ did not influence the X- or Y-bearing sperm of bovine in vitro (98). Therefore, extensive studies are needed to examine the effect of external $\mathrm{pH}$ on $\mathrm{X}$ - or Y-bearing sperm. We speculate that $\mathrm{pH}$ might affect $\mathrm{X}$ - or Y-bearing sperm by altering other physiochemical factors in the bovine oviduct. Furthermore, there have been several papers suggesting the effect of several glycoproteins and factors from the female reproductive tract on sperm survival including L-selectin (99), PMCA4 (100), fibronectin (101), SBG (102), etc. Hence, manipulating the sex of the offspring by regulating the expression level of these glycoproteins and factors is possible and could be a new direction for future research.

Above all, although sex manipulation in the female reproductive tract is the most parsimonious strategy proposed thus far, it has the potential of resolving the formerly puzzling and seemingly contradictory findings. With continued research, a better understanding of female influence in sex determination can be attained and could have a huge impact on existing sex manipulation strategies.

\section{EMBRYO SEXING IN SEX MANIPULATION}

Since artificial insemination and embryo transfer technology were implemented in commercial field, research on finding embryo sexing method has become a point of interest for 
modern researchers (103). Obstetric ultrasonography is the most common imaging technique in veterinary reproduction including: confirming pregnancy, identifying congenital fetal defects, defining fetal sex, etc., because it is simple, reliable, and non-invasive $(104,105)$. However, the sex of mammalian fetus cannot be performed by ultrasonographic examination until several weeks after pregnancy [e.g., 55-85 days in cattle (106), 59-68 days in horse (107), 46-55 days in goat (108)], which does not meet the requirements of embryo transfer as the main stage at which embryo transfer is performed is the cleavage stage (day 2-4 after fertilization) or the blastocyst stage (day 5 or 6 fertilization) (109). Thus, a large number of techniques for genetic sex identification of early embryo in mammals have since been developed. Before Barr body formation (110) or detection of H-Y antigen $(111,112)$, methods used were based on cytogenetic analysis $(113,114)$ and measurement of level of X-linked enzymes (glucose-6-phosphatase dehydrogenase, G6PD). However, due to the high embryo requirement, low accuracy, and the potential of embryo injuries, these methods were replaced by molecular detection.

The blastomere of mammalian embryos is omnipotent and can develop into a complete animal. Thus, each blastomere contains all the genes required for the development of an animal, including genes involved in sex determination such as Amg (115), Zfy (116), and Sry (117). Molecular biologic detection techniques, which include using nucleic acid probe, fluorescence in situ hybridization (FISH), polymerase chain reaction (PCR), and loop-mediated isothermal amplification (LAMP), can therefore be used to identify the male-specific gene.

Among nucleic acid probes, isotopic labeled probes have high accuracy but require a lot of embryo cells and time, while biotin-labeled probes require little time to detect but can only separate few embryos (118). FISH, on the other hand, has high accuracy and rapidity and can display a variety of colors due to the emergence of multi-color fluorescence in situ hybridization. FISH is however expensive and complex to operate (119), thereby leaving PCR and LAMP as the mainstream methods for embryo sexing in sex manipulation presently.

PCR is widely used, and besides its ability to analyze the phenotypes based on amplification products of sex-specific genes, it can verify the purity of sorted X-and Y-bearing sperm statistically. To identify the sex of embryos (120) through PCR, a pair of previously developed sex-specific primers was used. In 1991, this method successfully identified the sex of cattle and sheep embryos for the first time (121). However, since this method only amplified a pair of sex-specific primers, lack of amplification would correspond to a negative result. This method was therefore replaced by multiplex PCR in which a pair of sex-specific primers with at least one pair of internal primers that amplify house-keeping genes (122) was designed and utilized. However, due to the large number of cells required in the conventional PCR method and the limited sensitivity of one amplification, the method was prone to errors. Therefore, nested PCR and multiplex PCR were later combined to improve the accuracy of detection results. Besides increasing the amount of amplification product and the test's accuracy, the combination reduced the number of required cells to 3-8. In addition, conventional PCR has some disadvantages such as a complicated identification process and long identification time. Until 1992, Cha et al. adopted two-temperature gradient PCR to obtain the ideal amplification results. This proved that DNA polymerase could rapidly catalyze a complete amplification process from annealing to degeneration without extension steps when the fragment amplified is small $(<200 \mathrm{bp})$. Not only did this retain the advantages (high sensitivity, high accuracy, low embryonic damage) of conventional PCR, but it also simplified the conventional PCR and shortened the entire process from $2-4 \mathrm{~h}$ to $1 \mathrm{~h}(123)$.

Presently, PCR can be used for further analyses, such as genotyping and molecular diagnosis in preimplantation embryos besides embryo sexing (124). Moreover, it is feasible for automation and high-throughput sex-typing (125). Though not suitable for the sex manipulation of twin pregnancies (126), research has demonstrated that sex manipulation using the DNA of free fetal cells in maternal plasma is efficient for both $S R Y$ and $A M E L$ gene sequences.

Loop-mediated isothermal amplification (LAMP) is a method of DNA amplification that was developed by Eiken Chemical Co. Ltd. in 2000 and works under isothermal conditions. This method of DNA amplification is highly specific, efficient, and rapid (127). Besides, gene amplification and detection can be completed in one step, and amplification could be up to $10^{9}-10^{10}$ times in $15-60 \mathrm{~min}$. Since the detection of all target gene sequences can only be determined by either the presence or absence of amplification products, LAMP is considered to be highly specific. Recently, LAMP primers with polyethylenimine (PEI) for precipitation were optimized to improve sensitivity, and multiplex LAMP was used to improve accuracy (128). The first LAMP assay for the detection of the SRY gene was performed using DNA extracted from 15 blood samples from pregnant women at 8 weeks (129).

Although PCR and LAMP have made significant progress in embryo sexing owing to their high sensitivity, the impact of the pollution in the external environment on the accuracy of the results remains inevitable. In addition, these two methods are difficult to use in livestock production due to the large sample size and the poor transfer pregnancy rate of recent embryo transfer technology. Therefore, future research should focus on improving tolerance to external environment and the efficiency of these technologies. Besides, these technologies should be applied to identify the accuracy of other sex manipulation strategies, rather than as a sex manipulation strategy.

\section{CONCLUSION}

Sex manipulation technologies are valuable biotechnologies that have the potential to revolutionize cattle production. With the development of molecular biology and cell biology, these emerging sex manipulation strategies significantly expand the ability to bias the sex ratio of animal offspring and 
would be instrumental in correcting clinical male-to-female sex reversal syndrome in humans. However, the knowledge of sex-determining mechanisms, whether sex-determining gene or female reproductive tract, is still very limited. Since different sex manipulation strategies have their individual advantages and disadvantages, the selection of a specific system is dependent on the expertise of the individual researcher rather than on the weaknesses of one of these strategies. Collectively, sex determination is a complex process that is influenced by a variety of internal and external factors. Further exploration of sex-determining mechanisms; continuous improvement of the accuracy, sensitivity, and economic benefits of sex manipulation technologies; and the establishment of a new a sex manipulation system that integrates knowledge from various fields can provide great impetus in livestock production and solve the problem of food shortage.

\section{REFERENCES}

1. Stratonovitch P, Semenov MA. Heat tolerance around flowering in wheat identified as a key trait for increased yield potential in Europe under climate change. J Exp Bot. (2015) 66:3599-609. doi: 10.1093/jxb/erv070

2. Moda HM, Filho WL, Minhas A. Impacts of climate change on outdoor workers and their safety: some research priorities. Int J Environ Res Public Health. (2019) 16:3458. doi: 10.3390/ijerph16183458

3. Mccartney ES. Sex determination and sex control in antiquity. Am J Philol. (1922) 43:62-70. doi: 10.2307/289330

4. Stévant I, Papaioannou MD, Nef S. A brief history of sex determination. Mol Cell Endocrinol. (2018) 468:3-10. doi: 10.1016/j.mce.2018.04.004

5. Oppenheimer JM. Disputations touching the generation of animals. Essay review. Trans Stud Coll Phys Phila. (1982) 4:306-9.

6. Ruestow EG. Images and ideas: leeuwenhoek's perception of the spermatozoa. J Hist Biol. (1983) 16:185-224. doi: 10.1007/BF00124698

7. Stevens NM. Studies in Spermatogenesis. Washington, DC: Carnegie Institution of Washington. (1905). p. 2.

8. Palmer MS, Sinclair AH, Berta P, Ellis NA, Goodfellow PN, Abbas NE, et al. Genetic evidence that ZFY is not the testis-determining factor. Nature. (1989) 342:937-9. doi: 10.1038/342937a0

9. Sinclair AH, Berta P, Palmer MS, Hawkins JR, Griffiths BL, Smith MJ, et al. A gene from the human sex-determining region encodes a protein with homology to a conserved DNA-binding motif. Nature. (1990) 346:2404. doi: $10.1038 / 346240 \mathrm{a} 0$

10. Sekido R, Lovell-Badge R. Sex determination involves synergistic action of SRY and SF1 on a specific Sox9 enhancer. Nature. (2008) 453:9304. doi: $10.1038 /$ nature 06944

11. Foster JW, Dominguez-Steglich MA, Guioli S, Kwok C, Weller PA, Stevanović M, et al. Campomelic dysplasia and autosomal sex reversal caused by mutations in an SRY-related gene. Nature. (1994) 372:52530. doi: $10.1038 / 372525 \mathrm{a} 0$

12. Kim Y, Kobayashi A, Sekido R, Dinapoli L, Brennan J, Chaboissier MC, et al. Fgf9 and Wnt4 act as antagonistic signals to regulate mammalian sex determination. PLoS Biol. (2006) 4:e187. doi: 10.1371/journal.pbio.0040187

13. Jameson SA, Natarajan A, Cool J, Defalco T, Maatouk DM, Mork L, et al. Temporal transcriptional profiling of somatic and germ cells reveals biased lineage priming of sexual fate in the fetal mouse gonad. PLoS Genet. (2012) 8:e1002575. doi: 10.1371/journal.pgen.1002575

14. Koopman P, Sinclair A, Lovell-Badge R. Of sex and determination: marking 25 years of randy, the sex-reversed mouse. Development. (2016) 143:16337. doi: $10.1242 /$ dev.137372

15. Monaghan F, Corcos A. On the origins of the mendelian laws. J Hered. (1984) 75:67-9. doi: 10.1093/oxfordjournals.jhered.a109868

16. Eddy EM. Regulation of gene expression during spermatogenesis. Semin Cell Dev Biol. (1998) 9:451-7. doi: 10.1006/scdb.1998.0201

\section{AUTHOR CONTRIBUTIONS}

YX and ZX: conceived the idea, conducted the literature review, and drafted the manuscript. $\mathrm{ZW}$ and $\mathrm{LH}$ : project investigator, decided a review topic, and revised the manuscript. All the authors have read and approved the final version of the manuscript.

\section{FUNDING}

This work was supported by the Key-Area Research and Development Program of Guangdong Province (2018B020203002), the Guangdong Provincial Promotion Project on Preservation and Utilization of Local Breed of Livestock and Poultry (2018-143), and the Science and Technology Planning Project of Guangzhou (201904010434).

17. Zhao L, Koopman P. SRY protein function in sex determination: thinking outside the box. Chromosome Res. (2012) 20:15362. doi: 10.1007/s10577-011-9256-X

18. Gubbay J, Collignon J, Koopman P, Capel B, Economou A, Munsterberg $\mathrm{A}$, et al. A gene mapping to the sex-determining region of the mouse $\mathrm{Y}$ chromosome is a member of a novel family of embryonically expressed genes. Nature. (1990) 346:245-50. doi: 10.1038/346245a0

19. Shahed A, Young KA. Anti-mullerian hormone (AMH), inhibin-alpha, growth differentiation factor 9 (GDF9), and bone morphogenic protein-15 (BMP15) mRNA and protein are influenced by photoperiod-induced ovarian regression and recrudescence in siberian hamster ovaries. Mol Reprod Dev. (2013) 80:895-907. doi: 10.1002/mrd.22215

20. Polanco JC, Wilhelm D, Davidson TL, Knight D, Koopman P. Sox10 gain-of-function causes XX sex reversal in mice: implications for human 22q-linked disorders of sex development. Hum Mol Genet. (2010) 19:506-16. doi: 10.1093/hmg/ ddp520

21. Koopman P. Sex determination: a tale of two sox genes. Trends Genet. (2005) 21:367-70. doi: 10.1016/j.tig.2005.05.006

22. Matson CK, Murphy MW, Sarver AL, Griswold MD, Bardwell VJ, Zarkower D. DMRT1 prevents female reprogramming in the postnatal mammalian testis. Nature. (2011) 476:101-4. doi: 10.1038/nature10239

23. Bowles J, Feng CW, Spiller C, Davidson TL, Jackson A, Koopman P. FGF9 suppresses meiosis and promotes male germ cell fate in mice. Dev Cell. (2010) 19:440-9. doi: 10.1016/j.devcel.2010.08.010

24. $\mathrm{Hu}$ YC, Okumura LM, Page DC. Gata4 is required for formation of the genital ridge in mice. PLoS Genet. (2013) 9:e1003629. doi: 10.1371/journal.pgen.1003629

25. Jeays-Ward K, Dandonneau M, Swain A. Wnt4 is required for proper male as well as female sexual development. Dev Biol. (2004) 276:43140. doi: 10.1016/j.ydbio.2004.08.049

26. Vainio S, Heikkila M, Kispert A, Chin N, Mcmahon AP. Female development in mammals is regulated by Wnt-4 signalling. Nature. (1999) 397:4059. doi: 10.1038/17068

27. Ottolenghi C, Pelosi E, Tran J, Colombino M, Douglass E, Nedorezov T, et al. Loss of Wnt4 and Foxl2 leads to female-to-male sex reversal extending to germ cells. Hum Mol Genet. (2007) 16:2795-804. doi: 10.1093/hmg/ddm235

28. Swain A, Narvaez V, Burgoyne P, Camerino G, Lovell-Badge R. Dax1 antagonizes Sry action in mammalian sex determination. Nature. (1998) 391:761-7. doi: 10.1038/35799

29. Tomizuka K, Horikoshi K, Kitada R, Sugawara Y, Iba Y, Kojima A, et al. R-spondin1 plays an essential role in ovarian development through positively regulating Wnt-4 signaling. Hum Mol Genet. (2008) 17:127891. doi: $10.1093 / \mathrm{hmg} / \mathrm{ddn} 036$

30. Chassot AA, Ranc F, Gregoire EP, Roepers-Gajadien HL, Taketo MM, Camerino G, et al. Activation of beta-catenin signaling by Rspol controls 
differentiation of the mammalian ovary. Hum Mol Genet. (2008) 17:126477. doi: $10.1093 / \mathrm{hmg} / \mathrm{ddn} 016$

31. Takasawa K, Kashimada K, Pelosi E, Takagi M, Morio T, Asahara H, et al. FOXL2 transcriptionally represses Sf1 expression by antagonizing WT1 during ovarian development in mice. Faseb J. (2014) 28:20208. doi: 10.1096/fj.13-246108

32. Crisponi L, Deiana M, Loi A, Chiappe F, Uda M, Amati P, et al. The putative forkhead transcription factor FOXL2 is mutated in blepharophimosis/ptosis/epicanthus inversus syndrome. Nat Genet. (2001) 27:159-66. doi: 10.1038/84781

33. Uhlenhaut NH, Jakob S, Anlag K, Eisenberger T, Sekido R, Kress J, et al. Somatic sex reprogramming of adult ovaries to testes by FOXL2 ablation. Cell. (2009) 139:1130-42. doi: 10.1016/j.cell.2009.11.021

34. Kurtz S, Petersen B. Pre-determination of sex in pigs by application of CRISPR/Cas system for genome editing. Theriogenology. (2019) 137:6774. doi: 10.1016/j.theriogenology.2019.05.039

35. Yano A, Nicol B, Jouanno E, Guiguen Y. Heritable targeted inactivation of the rainbow trout (Oncorhynchus mykiss) master sexdetermining gene using zinc-finger nucleases. Mar Biotechnol. (2014) 16:243-50. doi: 10.1007/s10126-013-9546-8

36. Kato T, Miyata K, Sonobe M, Yamashita S, Tamano M, Miura K, et al. Production of Sry knockout mouse using TALEN via oocyte injection. Sci Rep. (2013) 3:3136. doi: 10.1038/srep03136

37. Fernandez A, Josa S, Montoliu L. A history of genome editing in mammals. Mamm Genome. (2017) 28:237-46. doi: 10.1007/s00335-017-9699-2

38. Hai T, Teng F, Guo R, Li W, Zhou Q. One-step generation of knockout pigs by zygote injection of CRISPR/Cas system. Cell Res. (2014) 24:3725. doi: 10.1038/cr.2014.11

39. Whitworth KM, Benne JA, Spate LD, Murphy SL, Samuel MS, Murphy CN, et al. Zygote injection of CRISPR/Cas9 RNA successfully modifies the target gene without delaying blastocyst development or altering the sex ratio in pigs. Transgenic Res. (2017) 26:97-107. doi: 10.1007/s11248-016-9989-6

40. Hauschild J, Petersen B, Santiago Y, Queisser AL, Carnwath JW, LucasHahn A, et al. Efficient generation of a biallelic knockout in pigs using zinc-finger nucleases. Proc Natl Acad Sci USA. (2011) 108:120137. doi: $10.1073 /$ pnas. 1106422108

41. Yosef I, Edry-Botzer L, Globus R, Shlomovitz I, Munitz A, Gerlic M, et al. A genetic system for biasing the sex ratio in mice. Embo Rep. (2019) 20:e48269. doi: 10.15252/embr.201948269

42. Tsoumani KT, Meccariello A, Mathiopoulos KD, Papathanos PA. Developing CRISPR-based sex-ratio distorters for the genetic control of fruit fly pests: a how to manual. Arch Insect Biochem Physiol. (2020) 103:e21652. doi: 10.1002/arch.21652

43. Song Y, Xu Y, Liang M, Zhang Y, Chen M, Deng J, et al. CRISPR/Cas9mediated mosaic mutation of SRY gene induces hermaphroditism in rabbits. Biosci Rep. (2018) 38:BSR20171490. doi: 10.1042/BSR20171490

44. Bode L, Contractor N, Barile D, Pohl N, Prudden AR, Boons GJ, et al. Overcoming the limited availability of human milk oligosaccharides: challenges and opportunities for research and application. Nutr Rev. (2016) 74:635-44. doi: 10.1093/nutrit/nuw025

45. Gabriels IJ, Vergauwen L, De Boevre M, Van Dongen S, Blust R, De Saeger S, et al. Optimizing the use of zebrafish feeding trials for the safety evaluation of genetically modified crops. Int J Mol Sci. (2019) 20:1472. doi: 10.3390/ijms20061472

46. Han H. RNA interference to knock down gene expression. Methods Mol Biol. (2018) 1706:293-302. doi: 10.1007/978-1-4939-7471-9_16

47. Elbashir SM, Harborth J, Lendeckel W, Yalcin A, Weber K, Tuschl T. Duplexes of 21-nucleotide RNAs mediate RNA interference in cultured mammalian cells. Nature. (2001) 411:494-8. doi: 10.1038/35078107

48. Zhang Y, Xi J, Jia B, Wang X, Wang X, Li C, et al. RNAi as a tool to control the sex ratio of mouse offspring by interrupting $\mathrm{Zfx} / \mathrm{Zfy}$ genes in the testis. Mamm Genome. (2017) 28:100-5. doi: 10.1007/s00335-017-9682-y

49. Wu N, Yu AB, Zhu HB, Lin XK. Effective silencing of Sry gene with RNA interference in developing mouse embryos resulted in feminization of XY gonad. J Biomed Biotechnol. (2012) 2012:343891. doi: 10.1155/2012/343891

50. Shahabipour F, Barati N, Johnston TP, Derosa G, Maffioli P, Sahebkar A. Exosomes: nanoparticulate tools for RNA interference and drug delivery. J Cell Physiol. (2017) 232:1660-8. doi: 10.1002/jcp.25766
51. Parrilla I, Vazquez JM, Oliver-Bonet M, Navarro J, Yelamos J, Roca J, et al. Fluorescence in situ hybridization in diluted and flow cytometrically sorted boar spermatozoa using specific DNA direct probes labelled by nick translation. Reproduction. (2003) 126:317-25. doi: 10.1530/rep.0.1260317

52. Kobayashi J, Kohsaka T, Sasada H, Umezu M, Sato E. Fluorescence in situ hybridization with $\mathrm{Y}$ chromosome-specific probe in decondensed bovine spermatozoa. Theriogenology. (1999) 52:1043-54. doi: 10.1016/S0093-691X(99)00193-4

53. Evans JM, Douglas TA, Renton JP. An attempt to separate fractions rich in human Y sperm. Nature. (1975) 253:352-4. doi: 10.1038/253352a0

54. Ericsson RJ, Langevin CN, Nishino M. Isolation of fractions rich in human $Y$ sperm. Nature. (1973) 246:421-4. doi: 10.1038/246421a0

55. Resende MV, Bezerra MB, Perecin F, Almeida AO, Lucio AC, De Lima VF. Separation of X-bearing bovine sperm by centrifugation in continuous percoll and optiprep density gradient: effect in sperm viability and in vitro embryo production. Ciencia Anim Brasileira. (2009) 2:581-7.

56. Aleahmad F, Gourabi H, Zeinali B, Kazemi A S, Baharvand H. Separation of X- and Y-bearing human spermatozoa by sperm isolation medium gradients evaluated by FISH. Reprod Biomed Online. (2009) 18:4758. doi: $10.1016 / \mathrm{S} 1472-6483(10) 60122-8$

57. Lobel SM, Pomponio RJ, Mutter GL. The sex ratio of normal and manipulated human sperm quantitated by the polymerase chain reaction. Fertil Steril. (1993) 59:387-92. doi: 10.1016/S0015-0282(16)5 5682-9

58. Beckett TA, Martin RH, Hoar DI. Assessment of the sephadex technique for selection of X-bearing human sperm by analysis of sperm chromosomes, deoxyribonucleic acid and Y-bodies. Fertil Steril. (1989) 52:829-35. doi: 10.1016/S0015-0282(16)53048-9

59. Steeno O, Adimoelja A, Steeno J. Separation of X- and Y-bearing human spermatozoa with the sephadex gel-filtration method. Andrologia. (1975) 7:95-7. doi: 10.1111/j.1439-0272.1975.tb01234.x

60. Hossain A, Islam MM, Naznin F, Ferdousi RN, Bari FY, Juyena NS. Quality of ram spermatozoa separated with modified swim up method. Bangladesh Vet. (2018) 33:62-70. doi: 10.3329/bvet.v33i2.36459

61. Repalle D, Chittawar PB, Bhandari S, Joshi G, Paranjape M, Joshi C. Does centrifugation and semen processing with swim up at 37 degrees C yield sperm with better DNA integrity compared to centrifugation and processing at room temperature? J Hum Reprod Sci. (2013) 6:236. doi: 10.4103/0974-1208.112375

62. Espinosa-Cervantes R, Córdova-Izquierdo A. Sexing sperm of domestic animals. Trop Anim Health Pro. (2012) 45:1-8. doi: 10.1007/s11250-012-0215-0

63. Johnson LA, Flook JP, Look MV. Flow cytometry of X and Y chromosome-bearing sperm for DNA using an improved preparation method and staining with hoechst 33342. Gamete Res. (1987) 17:20312. doi: $10.1002 / \mathrm{mrd} .1120170303$

64. Johnson LA, Clarke RN. Flow sorting of X and Y chromosomebearing mammalian sperm: activation and pronuclear development of sorted bull, boar, and ram sperm microinjected into hamster oocytes. Gamete Res. (1988) 21:335-43. doi: 10.1002/mrd.1120 210402

65. de Graaf SP, Beilby KH, Underwood SL, Evans G, Maxwell WMC. Sperm sexing in sheep and cattle: the exception and the rule. Theriogenology. (2009) 71:89-97. doi: 10.1016/j.theriogenology.2008.09.014

66. Vazquez JM, Roca J, Gil MA, Cuello C, Parrilla I, Caballero I, et al. Lowdose insemination in pigs: problems and possibilities. Reprod Domest Anim. (2008) 43:347-54. doi: 10.1111/j.1439-0531.2008.01183.x

67. Garner DL. Flow cytometric sexing of mammalian sperm. Theriogenology. (2006) 65:943-57. doi: 10.1016/j.theriogenology.2005.09.009

68. García EM, Vázquez JM, Parrilla I, Calvete JJ, Sanz L, Caballero I, et al. Improving the fertilizing ability of sex sorted boar spermatozoa. Theriogenology. (2007) 68:771-8. doi: 10.1016/j.theriogenology.2007.06.006

69. Maxwell WM, Johnson LA. Physiology of spermatozoa at high dilution rates: the influence of seminal plasma. Theriogenology. (1999) 52:135362. doi: 10.1016/S0093-691X(99)00222-8

70. Bathgate R. Functional integrity of sex-sorted, frozen-thawed boar sperm and its potential for artificial insemination. Theriogenology. (2008) 70:123441. doi: 10.1016/j.theriogenology.2008.06.009 
71. Vazquez JM, Parrilla I, Roca J, Gil MA, Cuello C, Vazquez JL, et al. Sex-sorting sperm by flow cytometry in pigs: issues and perspectives. Theriogenology. (2009) 71:80-8. doi: 10.1016/j.theriogenology.2008.09.044

72. Maxwell WMC, Long CR, Johnson LA, Dobrinsky JR, Welch GR. Viability and membrane integrity of spermatozoa after dilution and cytometric sorting in the presence or absence of seminal plasma. Reprod Fertil Dev. (1997) 8:1165-78. doi: 10.1071/RD9961165

73. Caballero I, Vazquez JM, Centurion F, Rodriguez-Martinez H, Parrilla I, Roca $\mathrm{J}$, et al. Comparative effects of autologous and homologous seminal plasma on the viability of largely extended boar spermatozoa. Reprod Domest Anim. (2004) 39:370-5. doi: 10.1111/j.1439-0531.2004.00530.x

74. Bailey JL, Bilodeau JF, Cormier N. Semen cryopreservation in domestic animals: a damaging and capacitating phenomenon. J Androl. (2000) 21:1-7.

75. Parrilla I, Vázquez JM, Cuello C, Gil MA, Roca J, Di Berardino D, et al. Hoechst 33342 stain and u.v. laser exposure do not induce genotoxic effects in flow-sorted boar spermatozoa. Reproduction. (2004) 128:61521. doi: 10.1530/rep.1.00288

76. Vazquez JM, Martinez EA, Parrilla I, Gil MA, Lucas X, Roca J. Motility characteristics and fertilizing capacity of boar spermatozoa stained with hoechst 33342. Reprod Domest Anim. (2002) 37:36974. doi: 10.1046/j.1439-0531.2002.00387.x

77. Guthrie HD, Johnson LA, Garrett WM, Welch GR, Dobrinsky JR. Flow cytometric sperm sorting: effects of varying laser power on embryo development in swine. Mol Reprod Dev. (2002) 61:87-92. doi: $10.1002 / \mathrm{mrd} .1134$

78. Suh TK, Schenk JL, Seidel GE. High pressure flow cytometric sorting damages sperm. Theriogenology. (2005) 64:103548. doi: 10.1016/j.theriogenology.2005.02.002

79. Garner DL, Evans KM, Seidel GE. Sex-sorting sperm using flow cytometry/cell sorting. Methods Mol Biol. (2013) 927:27995. doi: 10.1007/978-1-62703-038-0_26

80. Anel-Lopez L, Garcia-Alvarez O, Maroto-Morales A, Tarantini T, Del OD, Ortiz JA, et al. Optimization of protocols for Iberian red deer (Cervus elaphus hispanicus) sperm handling before sex sorting by flow cytometry. Theriogenology. (2017) 92:129-36. doi: 10.1016/j.theriogenology.2017.01.023

81. Umezu K, Hiradate Y, Numabe T, Hara K, Tanemura K. Effects on glycocalyx structures of frozen-thawed bovine sperm induced by flow cytometry and artificial capacitation. J Reprod Dev. (2017) 63:47380. doi: 10.1262/jrd.2017-065

82. Qin Y, Yang S, Xu J, Xia C, Li X, An L, et al. Deep insemination with sex- sorted cashmere goat sperm processed in the presence of antioxidants. Reprod Domest Anim. (2018) 53:11-9. doi: 10.1111/rda.13045

83. Fantinati P, Zannoni A, Bernardini C, Webster N, Lavitrano M, Forni M, et al. Laparoscopic insemination technique with low numbers of spermatozoa in superovulated prepuberal gilts for biotechnological application. Theriogenology. (2005) 63:806-17. doi: 10.1016/j.theriogenology.2004.05.005

84. Del OD, Parrilla I, Sanchez-Osorio J, Gomis J, Angel MA, Tarantini T, et al. Successful laparoscopic insemination with a very low number of flow cytometrically sorted boar sperm in field conditions. Theriogenology. (2014) 81:315-20. doi: 10.1016/j.theriogenology.2013.09.031

85. Bennett D, Boyse EA. Sex ratio in progeny of mice inseminated with sperm treated with H-Y antiserum. Nature. (1973) 246:308-9. doi: $10.1038 / 246308 \mathrm{a} 0$

86. Zavos PM. Preconception sex determination via intra-vaginal administration of H-Y antisera in rabbits. Elsevier. (1983) 20:235-40. doi: 10.1016/0093-691X(83)90219-4

87. Bradley MP. Immunological sexing of mammalian semen: current status and future options. Elsevier. (1989) 72:3372-80. doi: 10.3168/jds.S0022-0302(89)79500-X

88. Kawarasaki T, Welch GR, Long CR, Yoshida M, Johnson LA. Verification of flow cytometorically-sorted X- and Y-bearing porcine spermatozoa and reanalysis of spermatozoa for DNA content using the fluorescence in situ hybridization (FISH) technique. Theriogenology. (1998) 50:62535. doi: 10.1016/S0093-691X(98)00167-8

89. Umehara T, Tsujita N, Shimada M. Activation of Toll-like receptor $7 / 8$ encoded by the $\mathrm{X}$ chromosome alters sperm motility and provides a novel simple technology for sexing sperm. PLoS Biol. (2019) 17:e3000398. doi: 10.1371/journal.pbio.3000398
90. Miller DJ. Review: the epic journey of sperm through the female reproductive tract. Animal. (2018) 12:s110-20. doi: 10.1017/S1751731118000526

91. Rickard JP, Pool KR, Druart X, de Graaf SP. The fate of spermatozoa in the female reproductive tract: a comparative review. Theriogenology. (2019) 137:104-12. doi: 10.1016/j.theriogenology.2019.05.044

92. Almiñana C, Caballero I, Heath PR, Maleki-Dizaji S, Parrilla I, Cuello C, et al. The battle of the sexes starts in the oviduct: modulation of oviductal transcriptome by X and Y-bearing spermatozoa. BMC Genomics. (2014) 15:293. doi: 10.1186/1471-2164-15-293

93. Gutierrez-Adan A, Perez-Garnelo J, Granados J, Garde JJ, Perez-Guzman M, Pintado B, et al. Relationship between sex ratio and time of insemination according to both time of ovulation and maturational state of oocyte. Zygote. (1999) 7:37-43. doi: 10.1017/S0967199499000374

94. Dominko T, First NL. Relationship between the maturational state of oocytes at the time of insemination and sex ratio of subsequent early bovine embryos. Theriogenology. (1997) 47:1041-50. doi: 10.1016/S0093-691X(97)00061-7

95. Grant VJ, Irwin RJ. Follicular fluid steroid levels and subsequent sex of bovine embryos. J Exp Zool A Comp Exp Biol. (2005) 303A:11205. doi: 10.1002/jez.a.233

96. Grant VJ, Irwin RJ, Standley NT, Shelling AN, Chamley LW. Sex of bovine embryos may be related to mothers' preovulatory follicular testosterone. Biol Reprod. (2008) 78:812-5. doi: 10.1095/biolreprod.107.0 66050

97. Zhou J, Chen L, Li J, Li H, Hong Z, Xie M, et al. The semen $\mathrm{pH}$ affects sperm motility and capacitation. PLoS ONE. (2015) 10:e132974. doi: 10.1371/journal.pone.0132974

98. Raval NP, Shah TM, George L, Joshi CG. Effect of the pH in the enrichment of X or Y sex chromosome-bearing sperm in bovine. Vet World. (2019) 12:1299-303. doi: 10.14202/vetworld.2019.1299-1303

99. Yu L, Zheng Y, Feng Y, Ma F. Role of L-selectin on leukocytes in the binding of sialic acids on sperm surface during the phagocytosis of sperm in female reproductive tract. Med Hypotheses. (2018) 120:46. doi: 10.1016/j.mehy.2018.08.008

100. Al-Dossary AA, Strehler EE, Martin-Deleon PA. Expression and secretion of plasma membrane Ca2+-ATPase 4a (PMCA4a) during murine estrus: association with oviductal exosomes and uptake in sperm. PLoS ONE. (2013) 8:e80181. doi: 10.1371/journal.pone.0080181

101. Osycka-Salut CE, Martinez-Leon E, Gervasi MG, Castellano L, Davio C, Chiarante $\mathrm{N}$, et al. Fibronectin induces capacitationassociated events through the endocannabinoid system in bull sperm. Theriogenology. (2020) 153:91-101. doi: 10.1016/j.theriogenology.2020. 04.031

102. Teijeiro JM, Cabada MO, Marini PE. Sperm binding glycoprotein (SBG) produces calcium and bicarbonate dependent alteration of acrosome morphology and protein tyrosine phosphorylation on boar sperm. J Cell Biochem. (2008) 103:1413-23. doi: 10.1002/jcb.21524

103. Mara L, Pilichi S, Sanna A, Accardo C, Chessa B, Chessa F, et al. Sexing of in vitro produced ovine embryos by duplex PCR. Mol Reprod Dev. (2004) 69:35-42. doi: 10.1002/mrd.20147

104. Descoteaux L, Gnemmi G, Colloton J. Ultrasonography of the bovine female genital tract. Vet Clin North Am Food Anim Pract. (2009) 25:73352. doi: 10.1016/j.cvfa.2009.07.009

105. Meagher S, Davison G. Early second-trimester determination of fetal gender by ultrasound. Ultrasound Obstet Gynecol. (1996) 8:322-4. doi: 10.1046/j.1469-0705.1996.08050322.x

106. Beal WE, Perry RC, Corah LR. The use of ultrasound in monitoring reproductive physiology of beef cattle. J Anim Sci. (1992) 70:9249. doi: $10.2527 / 1992.703924 x$

107. Aurich C, Schneider J. Sex determination in horses - current status and future perspectives. Anim Reprod Sci. (2014) 146:34-41. doi: 10.1016/j.anireprosci.2014.01.014

108. Erdogan G. Ultrasonic assessment during pregnancy in goats - a review. Reprod Domest Anim. (2012) 47:157-63. doi: 10.1111/j.1439-0531.2011.01873.x

109. Dar S, Lazer T, Shah PS, Librach CL. Neonatal outcomes among singleton births after blastocyst versus cleavage stage embryo transfer: a systematic review and meta-analysis. Hum Reprod Update. (2014) 20:43948. doi: 10.1093/humupd/dmu001 
110. Williams TJ. A technique for sexing mouse embryos by a visual colorimetric assay of the X-linked enzyme, glucose 6-phosphate dehydrogenase. Theriogenology. (1986) 25:733-9. doi: 10.1016/0093-691X(86)90131-7

111. Goldberg EH. H-Y antigen and sex determination. Philos Trans R Soc Lond B Biol Sci. (1988) 322:73-81. doi: 10.1098/rstb.1988.0115

112. Wachtel S, Nakamura D, Wachtel G, Felton W, Kent M, Jaswaney V. Sex selection with monoclonal H-Y antibody. Fertil Steril. (1988) 50:35560. doi: 10.1016/S0015-0282(16)60086-9

113. Singh EL, Hare WCD. The feasibility of sexing bovine morula stage embryos prior to embryo transfer. Theriogenology. (1980) 14:4217. doi: 10.1016/0093-691X(80)90053-9

114. Gardner RL, Edwards RG. Control of the sex ratio at full term in the rabbit by transferring sexed blastocysts. Nature. (1968) 218:3469. doi: $10.1038 / 218346 \mathrm{a} 0$

115. Gokulakrishnan P, Kumar RR, Sharma BD, Mendiratta SK, Sharma D. Sex determination of cattle meat by polymerase chain reaction amplification of the DEAD box protein (DDX3X/DDX3Y) gene. Asian-Aus J Anim Sci. (2012) 25:733-7. doi: 10.5713/ajas.2012.12003

116. Aasen E, Medrano JF. Amplification of the ZFY and ZFX genes for sex identification in humans, cattle, sheep and goats. Biotechnology. (1990) 8:1279-81. doi: 10.1038/nbt1290-1279

117. Pomp D, Good BA, Geisert RD, Corbin CJ, Conley AJ. Sex identification in mammals with polymerase chain reaction and its use to examine sex effects on diameter of day-10 or-11 pig embryos. J Anim Sci. (1995) 73:1408-15. doi: 10.2527/1995.7351408x

118. Bondioli KR, Ellis SB, Pryor JH, Williams MW, Harpold MM. The use of male-specific chromosomal DNA fragments to determine the sex of bovine preimplantation embryos. Elsevier. (1989) 31:95-104. doi: 10.1016/0093-691X(89)90567-0

119. Lavery S. Preimplantation genetic diagnosis: new reproductive options for carriers of haemophilia. Haemophilia. (2004) 10:126-32. doi: 10.1111/j.1365-2516.2004.01042.x

120. Chrenek P, Boulanger L, Heyman Y, Uhrin P, Laurincik J, Bulla J, et al. Sexing and multiple genotype analysis from a single cell of bovine embryo. Theriogenology. (2001) 55:1071-81. doi: 10.1016/S0093-691X(01)00467-8

121. Herr CM, Reed KC. Micronanipulation of bovine embryos for sex determination. Elsevier. (1991) 35:4554. doi: 10.1016/0093-691X(91)90147-6
122. Tienan Z, Jichang L, Chengwu L, Guicheng H. A multiplex PCR assay for the detection of pathogenic genes of EPEC, ETEC and EIEC. J Northeast Agric Univ. (2006) 13:51-4.

123. Cha RS, Zarbl H, Keohavong P, Thilly WG. Mismatch amplification mutation assay (MAMA): application to the c-H-ras gene. Genome Res. (1992) 2:1420. doi: 10.1101/gr.2.1.14

124. Tavares KCS, Carneiro IS, Rios DB, Feltrin C, Ribeiro AKC, GaudencioNeto S, et al. A fast and simple method for the polymerase chain reaction-based sexing of livestock embryos. Genet Mol Res. (2016) 15:gmr.15017476. doi: 10.4238/gmr.15017476

125. Blanes MS, Tsoi SCM, Dyck MK. Accurate and phenol free DNA sexing of day 30 porcine embryos by PCR. J Visual Exp. (2016) 14:53301. doi: 10.3791/53301

126. Saberivand A, Ahsan S. Sex determination of ovine embryos by SRY and amelogenin (AMEL) genes using maternal circulating cell free DNA. Anim Reprod Sci. (2016) 164:9-13. doi: 10.1016/j.anireprosci.2015.10.011

127. Yonekawa T, Notomi T, Watanabe K, Masubuchi H, Okayama H, Amino $\mathrm{N}$, et al. Loop-mediated isothermal amplification of DNA. Nucleic Acids Res. (2000) 28:E63. doi: 10.1093/nar/28.12.e63

128. Khamlor T, Pongpiachan P, Parnpai R, Punyawai K, Sangsritavong $\mathrm{S}$, Chokesajjawatee N. Bovine embryo sex determination by multiplex loop-mediated isothermal amplification. Theriogenology. (2015) 83:8916. doi: 10.1016/j.theriogenology.2014.11.025

129. Almasi MA, Almasi G. Loop mediated isothermal amplification (LAMP) for embryo sex determination in pregnant women at eight weeks of pregnancy. J Reprod Infertil. (2017) 18:197-204.

Conflict of Interest: The authors declare that the research was conducted in the absence of any commercial or financial relationships that could be construed as a potential conflict of interest.

Copyright (c) $2020 \mathrm{Xie}, \mathrm{Xu}, \mathrm{Wu}$ and Hong. This is an open-access article distributed under the terms of the Creative Commons Attribution License (CC BY). The use, distribution or reproduction in other forums is permitted, provided the original author(s) and the copyright owner(s) are credited and that the original publication in this journal is cited, in accordance with accepted academic practice. No use, distribution or reproduction is permitted which does not comply with these terms. 